UDC: 531.383

\author{
V.V. Chikovani, H.V. Tsiruk
}

National Aviation University, Kyiv

\title{
EFFECTIVE REJECTION OF ACOUSTIC AND MAGNETIC FIELDS' DISTURBANCES BY SINGLE-MASS DIFFERENTIAL VIBRATORY GYROSCOPE
}

\begin{abstract}
Differential mode of operation as a third mode unlike the first one - rate and second one - rateintegrating modes of vibratory gyroscopes is analyzed in this paper. In the differential mode of operation the standing wave is keeping in between the electrodes. In this case two $X$ and $Y$ measurement channels are created with opposite signs of angle rates. Biases and scale factors of $X$ and $Y$ measurement channels are dependant on standing wave angular position $\theta$ relative to drive, $X$, electrode. There is angular position $\theta^{*}$ at which $X$ measurement channel scale factor $S F_{x}$ is equal to $Y$ measurement channel scale factor $S F_{y}$. Rejection factors of external acoustic impulses which frequency is close to resonant one, and also of constant and variable magnetic fields are experimentally determined in this paper when standing wave angle is located at the $\theta^{*}$ angular position. As opposed to other types of differential gyros that can be implemented using two or multi-mass resonator designs, single-mass resonator gyros can have higher rejection factors for different disturbances at the $\theta^{*}$ angular position of standing wave providing meeting the requirements of many important applications. Test results show excellent disturbance rejection properties of differential mode of operation for single-mass resonator gyros. Comparison of responses of the differential mode with the rate mode of the same gyro on disturbances is also carried out in this work.
\end{abstract}

Key words: Differential gyroscope, rejection factor, acoustic disturbance, sensitivity to magnetic field.

\section{Introduction}

There are two well-known mode of CVG operation - rate mode and rate-integrating one [1,2]. Comparatively recent investigations $[3,4]$ resulted in the third, differential, mode of CVG operation with higher shock damping [5] and noise compensation [6] ability than the first two modes.

The differential mode of operation, which is analyzed in this paper, can be implemented in a single-mass Coriolis vibratory gyro (CVG) by keeping a standing wave between the electrodes by applying two stable amplitude control signals on $X$ and $Y$ drive axes electrodes. In this case two magnitudes of angular rates with opposite signs can be read-out from $X$ and $Y$ sense axes electrodes [7]. The resulting angular rate can be obtained by signals subtraction of two $X$ and $Y$ measurement channels, and at the proper alignment of standing wave, under angle of $\theta^{*}$ to $X$ drive electrode at which scale factors of the two channels, $S F_{x}$ and $S F_{y}$ are equal to each other, cross damping bias component is compensated for. Moreover, the sum of these two signals gives information about the bias components without angular rate that may be used to estimate certain bias components for on-line compensation [3].

As opposed to other types of differential gyros that can be implemented using two or multi-mass resonator designs, single-mass resonator gyros can have higher rejection factors for different disturbances allowing meeting the requirements of many important applications. CVG uses resonator as a rule of sound frequency to detect rotation. Hence, it is obvious that it can be disturbed by the external sound which frequency is close to resonant one or noisy sound which frequency range covers the resonant one. Test results show excellent disturbance rejection properties of differential mode of operation for single-mass vibratory gyro. Comparison of responses of the differential mode with the rate mode of the same gyro to external acoustic impulses which frequency are close to resonant one, constant and variable magnetic fields are made in this work.

\section{Problem statement}

There is well-known problem of acoustic disturbances influence on the CVG using sound frequency resonator when acoustic disturbances spectrum covers resonant frequency. There is also external magnetic field influence on the CVG electronics and resonator when it made of or covered with magnetic materials. This paper experimentally investigates the problem of rejection acoustic and magnetic fields for the metallic resonator CVG operating in differential mode.

\section{Differential CVG}

Because rate and rate-integrating modes of CVG operation are widely described in technical literature [1], [2], [8] and many others, let's shortly describe the differential mode of operation for singlemass resonator gyro. 
Let's apply control forces $f_{x}$ and $f_{y}$ on the $X$ and $Y$ electrodes such that standing wave is located in between the $X$ and $Y$ electrodes, as it is shown by dashed line in fig.1. Dynamic equations of the two dimensional pendulum [1] in this case can be written down as follows:

$$
\begin{aligned}
& \ddot{x}+d_{x x} \dot{x}+k_{x x} x+k_{x y} y=\left(2 k \Omega-d_{x y}\right) \dot{y}+f_{x} ; \\
& \ddot{y}+d_{y y} \dot{y}+k_{x y} x+k_{y y} y=\left(-2 k \Omega-d_{x y}\right) \dot{x}+f_{y} ;
\end{aligned}
$$

where $k$ is Brian coefficient, $d_{x x}=2 / \tau+\Delta(1 / \tau) \cos 2\left(\theta-\theta_{\tau}\right)$ is $X$ axis damping coefficient, $2 / \tau=1 / \tau_{1}+1 / \tau_{2}$, $\Delta(1 / \tau)=1 / \tau_{1}-1 / \tau_{2}$, where $\tau_{1}$ is minimum resonator's damping time, $\tau_{2}$ is maximum resonator's damping time

$d_{x y}=\Delta(1 / \tau) \sin 2\left(\theta-\theta_{\tau}\right)$ is damping cross-coupling, $k_{x x}=\omega_{1}{ }^{2}-\omega \Delta \omega \cos 2\left(\theta-\theta_{\omega}\right)$ is normalized by mass resonator rigidity along $X$ axis, $\omega \Delta \omega=\left(\omega_{1}^{2}-\omega_{2}^{2}\right) / 2$ where $\omega_{1}, \omega_{2}$ are maximum and minimum resonant frequencies, $k_{x y}=-\omega \Delta \omega \sin 2\left(\theta-\theta_{\omega}\right)$ is rigidity crosscoupling, $d_{y x}=d_{x y}, \quad d_{y y}=2 / \tau-\Delta(1 / \tau) \cos 2\left(\theta-\theta_{\tau}\right)$ is $Y$ axis damping coefficient, $k_{y x}=k_{x y}, k_{y y}=\omega_{2}{ }^{2}+\omega \Delta \omega \cos 2\left(\theta-\theta_{\omega}\right)$ is normalized by mass resonator rigidity along $Y$ axis, $f_{x}, f_{y}$ are normalized by mass control signals, $\theta_{\omega}$ is an angle between minimum frequency axis and standing wave (antinode) axis, $\theta_{\tau}$ is angle between minimum damping axis and standing wave (antinode) axis.

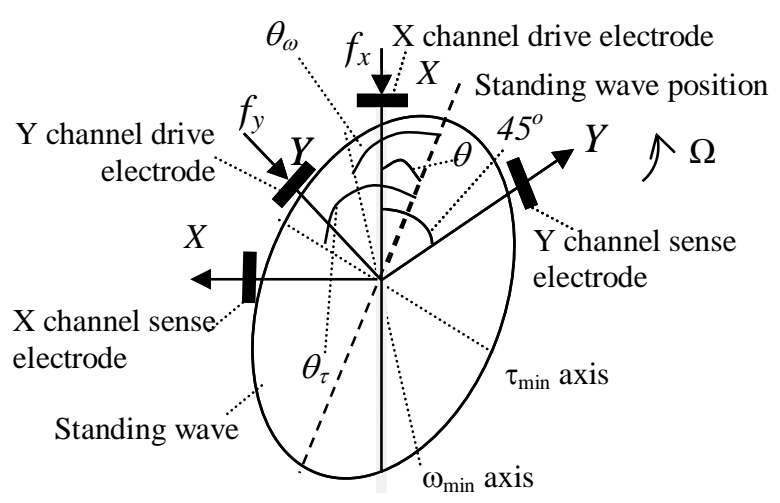

Fig. 1. Standing wave with drive and sense electrodes, $\tau_{\min }$ and $\omega_{\min }$ axes disposition in CVG resonator.

Usually, quadrature signal $Q$ associated with frequency mismatch is compensated for by well-known procedure [8], which can be represented as follows:

$$
Q=\pi(x \dot{y}-\dot{x} y) \rightarrow \text { null }
$$

In this case oscillation frequencies along both $X$ and $Y$ axes are almost equal to each other at the value $\omega_{r}$. Stationary solution of equations (1) when $\omega_{1}=\omega_{2}=\omega_{r}$ can be found as follows:

$$
x=A \cos 2 \theta \sin \left(\omega_{r} t\right) ; y=A \sin 2 \theta \sin \left(\omega_{r} t+\varphi\right)
$$

where $\varphi$ is a phase difference between $X$ and $Y$ sense electrode signals, $A$ is standing wave amplitude, $\theta$ is the angle between $X$ axis and standing wave oscillation direction. This solution transformed into output signals in voltages for $\varphi=0$ results in the following measurement equations [6]:

$$
\begin{gathered}
-2 k \Omega D_{y} \sin 2 \theta+D_{x} d_{x x} \cos \theta+d_{x y} D_{y} \sin 2 \theta=z_{x} ; \\
2 k \Omega D_{x} \cos 2 \theta+D_{y} d_{y y} \sin \theta+d_{x y} D_{x} \cos 2 \theta=z_{y},
\end{gathered}
$$

where $\mathrm{z}_{\mathrm{x}}, z_{y}, D_{x}, D_{y}$ are $\mathrm{X}$ and $\mathrm{Y}$ channel measurement signals in voltages and deformation-to-voltage conversion coefficients, respectively.

These measurement equations show that differential gyro gives us information about $-\Omega$ and $\Omega$, from $X$ and $Y$ sense electrodes, respectively. Based on equations (4), expressions for $X$ and $Y$ channel scale factors, $S F_{x}, \mathrm{~S} F_{y}$, and biases, $B_{x}, B_{y}$, can be presented as follows:

$$
\begin{aligned}
& S F_{x}=2 k D_{y} \sin 2 \theta ; B_{x}=D_{x} d_{x x} \cos 2 \theta+d_{x y} D_{y} \sin 2 \theta \\
& S F_{y}=2 k D_{x} \cos 2 \theta ; B_{y}=D_{y} d_{y y} \sin 2 \theta+d_{x y} D_{x} \cos 2 \theta
\end{aligned}
$$

It should be noted that both channel biases and scale factors are changed periodically versus standing wave angle $\theta$. Dependencies of $X$ and $Y$ channel biases and scale factors versus angle $\theta$ are presented in [4]. Thus, there is the angle $\theta_{0}$ that equalizes $X$ and $Y$ channel biases

$$
\begin{aligned}
& D_{x} d_{x x} \cos 2 \theta_{0}+d_{x y} D_{y} \sin 2 \theta_{0}= \\
& =D_{y} d_{y y} \sin 2 \theta_{0}+d_{x y} D_{x} \cos 2 \theta_{0} .
\end{aligned}
$$

Solution for $\theta 0$ yields

$$
\theta_{0}=\frac{1}{2} a \tan \frac{D_{x}}{D_{y}} \frac{d_{x x}-d_{x y}}{d_{y y}-d_{x y}} .
$$

When standing wave angle is $\theta_{0}$, difference of the two $X$ and $Y$ channel measurements, $z_{y}-z_{x}$, cancels bias and increases angle rate signal. In this case zero bias measurements can be obtained. For most sensors $D_{x} \approx$ $D_{y}, d_{x x} \approx d_{y y}$, and $d_{x x}<<d_{x y}$, so $\theta_{0} \approx \pi / 8=22.5^{\circ}$.

There is also standing wave angle $\theta^{*}$ that equalizes $X$ and $Y$ channel scale factors

$$
\begin{gathered}
2 k D_{y} \sin 2 \theta^{*}=2 k D_{x} \cos 2 \theta^{*} ; \\
\theta^{*}=\frac{1}{2} a \tan \frac{D_{x}}{D_{y}}=\frac{1}{2} a \tan \left(\frac{S F_{y}^{\theta}}{S F_{x}^{\theta}} \tan 2 \theta\right),
\end{gathered}
$$

where $S F_{x}^{\theta}$ and $S F_{y}^{\theta}$ are $X$ and $Y$ channel scale factors at standing wave angle $\theta$. The angle $\theta^{*}$ is also close to $\pi / 8$.

When standing wave angle is $\theta^{*}$, the difference, $z_{y^{-}}$ $z_{x}$, and sum, $z_{y}+z_{x}$, of two $X$ and $Y$ channel measurement signals are:

$$
z_{y}-z_{x}=S F_{d}\left(\Omega+\frac{d_{y y}-d_{x x}}{4 k}\right)
$$




$$
\begin{gathered}
S F_{d}=4 k \frac{D_{x} D_{y}}{\sqrt{D_{x}^{2}+D_{y}^{2}}} . \\
z_{y}+z_{x}=\frac{\mathrm{SF}_{d}}{4 k}\left[d_{y y}+d_{x x}+d_{x y}\left(1+\operatorname{ctg} 2 \theta^{*}\right)\right] .
\end{gathered}
$$

The differential channel (eq. (9)) does not contain damping cross-coupling $d_{x y}$, and sum of the two channels (eq. (11)) does not contain angle rate and can be used for on-line estimation of bias parameters $d_{x x}, d_{y y}$ and differential gyro scale factor $S F_{d}$ when $k$ is known. It should be noted that $S F_{d}$ does not depend on resonant frequency and vibration amplitude in contrast to conventional rate mode CVG [1]. Differential CVG output signals are presented in fig. 2 .
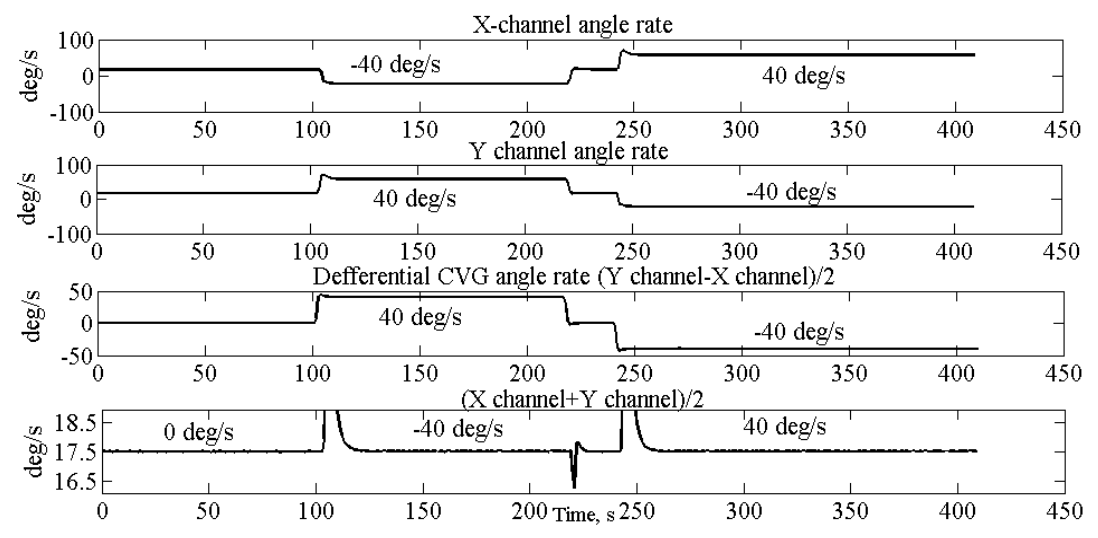

Fig.2. Differential CVG output signals

The first two sub-graphs show high enough biases determined by $d_{x x}$ and $d_{y y}$ (see $B_{x}$ and $B_{y}$ in (5)). The third sub-graph shows close to zero bias of differential channel, because $\left(d_{y y}-d_{x x}\right) / 2=-h \cos 2\left(\theta^{*}-\theta_{\tau}\right)$, and $h$ is close to zero. The fourth sub-graph represents $z_{y}+z_{x}$ as a combination of differential CVG bias parameters (see (9)). It is mainly determined by the large enough term $\left(d_{y y}+d_{x x}\right) / 2=2 / \tau$.

\section{Rejection factor determination}

Since each of the two $X$ and $Y$ measurement channels operate, in essence, in the rate mode and their difference represents differential mode signal, then ratio of one of the $X$ and $Y$ channel signals to half difference one, $(X-Y) / 2$, will determine rejection factor $R_{s}$ of CVG rate mode as compared with differential one. Ratio will be determined after bias subtraction for each of the channels. Thus, rejection factor for external acoustic impulse will be calculated as follows:

$$
R_{s}=\min _{i}\left\{\frac{\operatorname{mean}\left(a b s\left(X_{i}\right)\right)}{\text { mean }\left[a b s \frac{X_{i}-Y_{i}}{2}\right]}, \frac{\text { mean }\left(a b s\left(Y_{i}\right)\right)}{\text { mean }\left[a b s \frac{X_{i}-Y_{i}}{2}\right]}\right\} ;
$$

where, $X_{i}$ and $Y_{i}$ are peak values of $X$ and $Y$ channel responses for an $\underline{i}$-th exposure, $n$ is a number of exposures.

\section{Acoustic impulse rejection factor}

It is well known that resonant gyroscopes, including MEMS, degrade their performances when external disturbance is acting at a close to resonant frequency of the vibrating structure [9]. Acoustic signals can find way to $\mathrm{CVG}$ resonator through inducing mechanical vibrations of the gyro casing and anchors to which the resonator is attached. Acoustic impulse at the resonant frequency produces resonance response in the vibrating structure. This response is passing through control system without suppression and appears on the gyro output as a wrong angle rate. The higher the resonator $Q$ factor the larger the wrong angle rate on the output, because resonator $Q$ times amplifies disturbance at its resonant frequency. Also, the more the sound pressure level (SPL) of acoustic impulse the larger the wrong angle rate arises on the output. High $Q$ factor resonator can effectively suppress acoustic impulse which frequency defers from resonant one, because resonator is a band pass mechanical filter which bandwidth is inversely proportional to its $Q$ factor. Otherwise, low $Q$ factor resonator less amplifies acoustic disturbance, but also less suppress the disturbances which defers from its resonant frequency. So, in both cases resonant frequency should be protected from external acoustic impulse or noise with frequency close to resonator working frequency. Many investigators tried to mitigate the effect of acoustic noise on the MEMS gyros by using some types of foams [10] or other acoustic materials [11]. They also used multi-resonator design to implement differential measurements [12]. Micro-Helmholtz resonators have also been designed and manufactured in [11] to reach attenuation of the acoustic noise at the level of up to $18 \mathrm{~dB}$. 
This section presents test results on influence of acoustic impulses with frequencies close to resonant one on output signal of low Q factor differential vibrating gyro being under testsIn these tests acoustic impulses are entered into resonator by acoustic wave excitation of upper part of the CVG housing which source has a direct mechanical contact with its metallic housing. Sound intensity level of acoustic impulse was about 60 dB. Figure 3 shows differential CVG signal responses to three acoustic impulses. Sound impulse rejection factors, in terms of peak value, $\underline{R}_{s p}$, calculated using (10), give the following results: $\underline{R}_{s p l}=69.7 / 0.6 \approx 116$, $\underline{R}_{s p 2}=45.6 / 0.7 \approx 65$ and $\underline{R}_{s p 3}=82.2 / 0.8 \approx 103$. Minimum of three is $\underline{R}_{s p}=65$, that is about $36 \mathrm{~dB}$.

Figure 4 shows differential CVG output signals after exposure by acoustic impulses of approximately same intensity level which frequency is about $100 \mathrm{~Hz}$ farther than that of shown in figure 3.

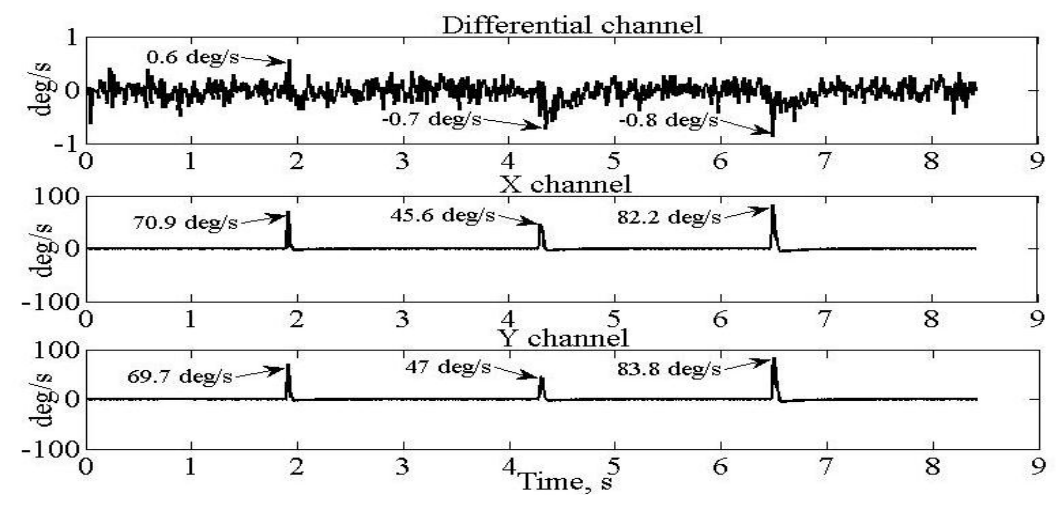

Fig. 3. Differential CVG responses to acoustic impulses close to its resonant frequency
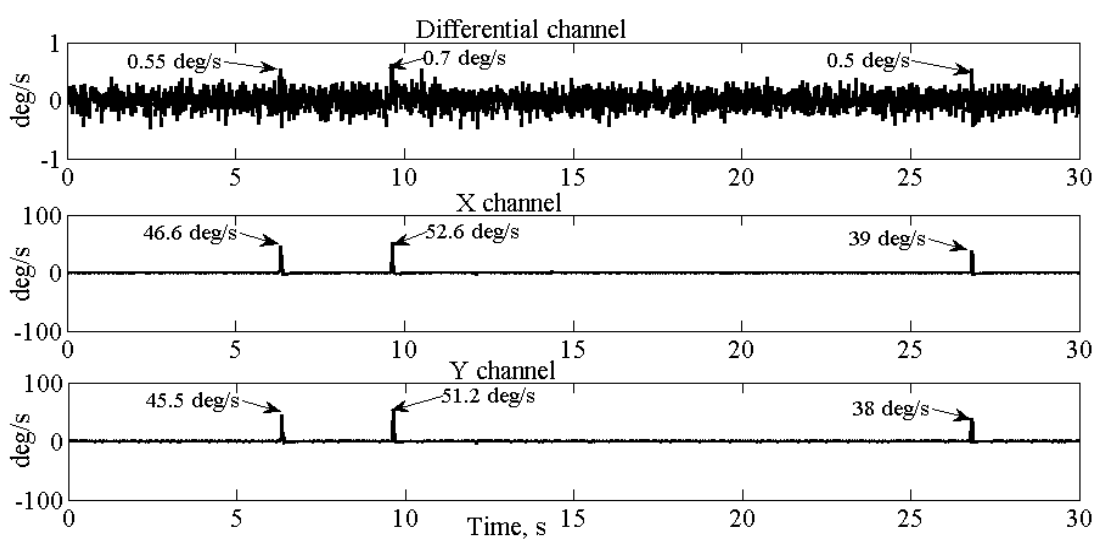

Fig. 4. Differential CVG response to acoustic impulses of $100 \mathrm{~Hz}$ farther from resonant

Acoustic impulse rejection factors for this case are $R_{s p 1}=45.5 / 0.55 \approx 83, \quad R_{s p 2}=51.2 / 0.7 \approx 73 \quad$ and $R_{s p 3}=38 / 0.5 \approx 76$. Minimum of three is $R_{s}=76$, that is about $38.6 \mathrm{~dB}$.

Thus, differential CVG, when standing wave position is $\theta^{*}$, rejects acoustic impulse close to resonant frequency more effectively, than ordinary rate mode CVG and micro-Helmholtz resonators [11].

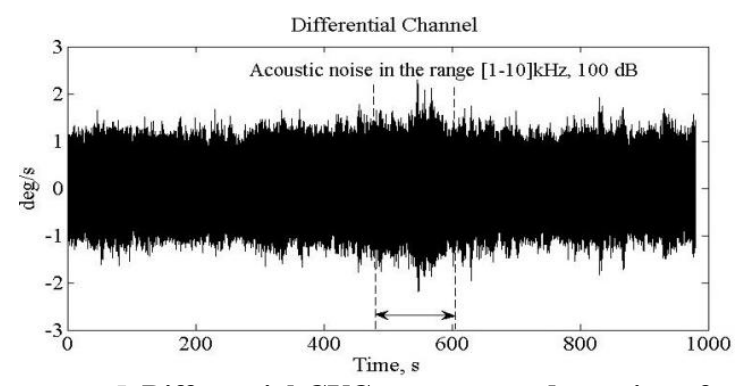

Fig.5. Differential CVG response under action of wide band noisy acoustic field of $100 \mathrm{~dB}$
Fig.5 shows output of differential channel under uniform intensity of $100 \mathrm{~dB}$ from all directions in the range of [1-10] $\mathrm{kHz}$.

Vertical dashed lines show time interval of acoustic noise action. As can be seen differential channel responds to acoustic noise with a little, no more than $10 \%$, increasing in the gyro output noise without changing in bias [13]. Magnetic field rejection factor

Gyroscopes are usually operate in a moving vehicle in surrounding of other devices, motors, electric generators and others which create magnetic field of different directions. Constant and/or variable magnetic fields influence on a gyroscope bias through interaction with electronic circuits and resonator when it made of or covered with magnetic materials. The amount of interaction with resonator depends on resonator material and amount of potential applied to it. This interaction results in gyro bias variation proportional to external magnetic field applied. So, it is very important to 
protect gyros from external magnetic field. This section presents test results that demonstrate high magnetic field rejection factor of differential $\mathrm{CVG}$ and much lower magnetic sensitivity in comparison with rate CVG.

\section{Magnetic Field Perpendicular to input axis}

Figure 6 shows differential CVG output signal biases under applied magnetic field of different magnitudes. One can see that differential channel does not visually reveal dependency on magnetic field whereas $X$ and $Y$ rate channels show up significant changes in biases.

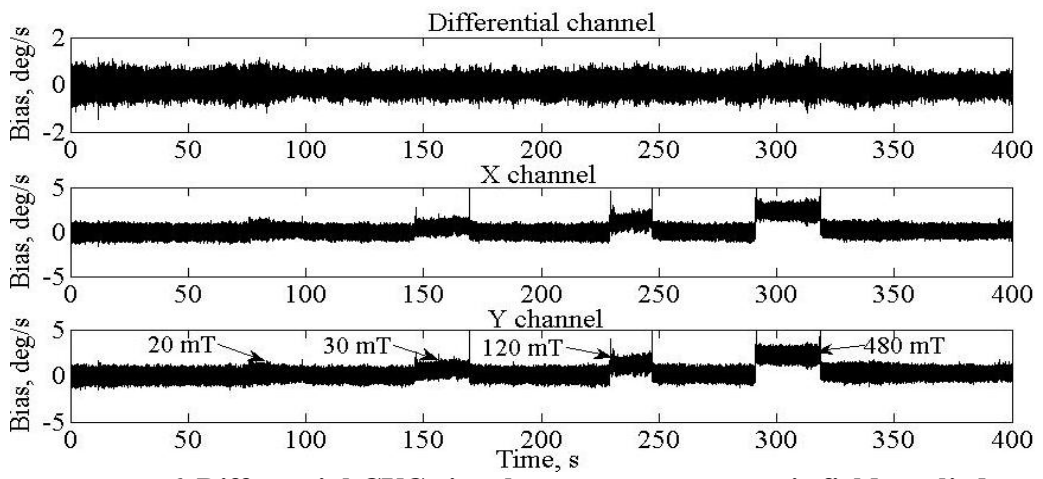

Fig. 6. Differential CVG signal responses to magnetic field applied

Excellent rejection property of differential signal is due to almost equal responses to magnetic field both $X$ and $Y$ channels. It is because signals of $X$ and $Y$ channels are generated by single mass resonator to which a magnetic field is applied.

Bias change for each of these three channels $X, Y$, and differential one versus magnetic field intensity is depicted in fig. 7.

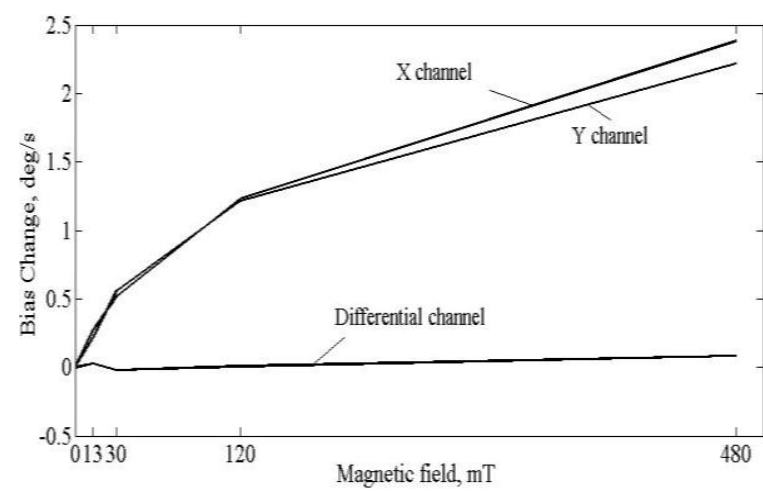

Fig. 7. Differential CVG channels sensitivities to magnetic field applied

This figure visually shows that differential signal magnetic field sensitivity is much lower than that of $X$ and $Y$ rate channels. Each of three channels magnetic field sensitivity coefficients can be quantitatively estimated by a tangent of tilt angles of least squares straight line drawn by the data presented in fig. 6 . The results are the following: $X$ channel magnetic field sensitivity is $\underline{S}_{m, x} \approx 4.54 * 10^{-3} \mathrm{deg} / \mathrm{s} / \mathrm{mT} ; Y$ channel is $S_{m, y} \approx 4.2 * 10^{-3} \mathrm{deg} / \mathrm{s} / \mathrm{mT}$ and differential channel is $S_{m, d} \approx 1.7 * 10^{-4} \mathrm{deg} / \mathrm{s} / \mathrm{mT}$. The ratio of minimum of $X$ and $Y$ channels sensitivity to that of differential one can be defined as a rejection factor to magnetic field perpendicular to gyro IA in comparison to rate CVG. It is equal to $R_{m p}=S_{m y} / S_{m d} \approx 25$.

Figure 8 shows responses of differential CVG signals to variable magnetic field with amplitude close to $10 \mathrm{mT}$. Differential channel does not show change in bias, because noise does not allow us to see the bias change at $10 \mathrm{mT}$ magnetic field.



Fig. 8. Differential CVG signal responses to a variable magnetic field applied

\section{Magnetic field along input axis}

Figure 9 shows bias change for each of three channels, $X, Y$, and differential one under different magnitudes of magnetic field applied along gyro IA. Behavior features of bias changes, presented in fig. 7 and 8 for both perpendicular and along IA directions of magnetic field are similar. Differential CVG channels magnetic field sensitivities along IA are: for $\underline{X}$ channel it is $S_{m, x}=1.3 * 10^{-2} \mathrm{deg} / \mathrm{s} / \mathrm{mT}$, for $Y$ channel it is $S_{m, y}=1.2 * 10^{-2} \mathrm{deg} / \mathrm{s} / \mathrm{mT}$ and for differential channel it is 
$S_{m, d}=1.3 * 10^{-3} \mathrm{deg} / \mathrm{s} / \mathrm{mT}$. Thus, rejection factor for magnetic field along gyro IA is $R_{m a}=S_{m y} / S_{m d} \approx 10$.

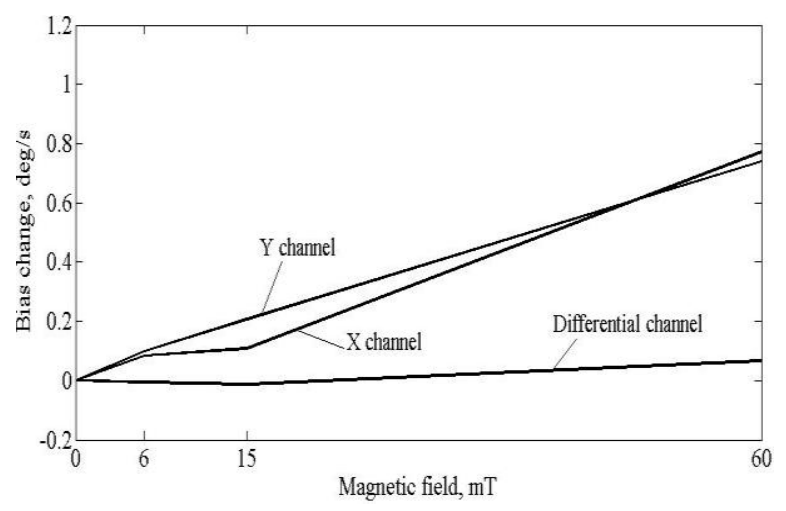

Fig. 9. Differential CVG channels sensitivities to magnetic field applied

Significant difference in rejection factors for different magnetic field directions is caused, most likely, by the difference in range of magnetic fields which were applied, than the change in directions of the field. One can see from the fig. 7 in spite of responses to magnetic field of both $X$ and $Y$ channels increase, the difference channel remains in the region of lower sensitivity. Based on this fact one can suppose that the greater the magnetic field, the greater the rejection factor of differential CVG in comparison to rate one.

\section{Conclusion}

Differential CVG can be considered as third mode of operation for vibratory gyroscopes along with two well known rate and rate-integrating ones. This mode of operation can be built-in the single gyro together with the two others, rate and rate-integrating modes, to implement triple-mode CVG. Triple-mode $g$

yro can be implemented both for MEMS and non MEMS vibratory gyros.

Acoustic impulse close to resonant frequency results in peak response in three informative channels of differential CVG. However, differential CVG rejection factors are $65(36 \mathrm{~dB})$ and $76(37.6 \mathrm{~dB})$ times more than those of for rate $\mathrm{CVG}$. These rejection factors are significantly higher than that of one that can reach using micro-Helmholtz resonators.

Investigation of acoustic disturbances influence on differential CVG output signals will be continued for wide band acoustic noise covered resonant frequency.

Magnetic field sensitivity for differential CVG is much less than that of for rate CVG for both along and perpendicular to gyro IA directions of magnetic field. Specifically, differential CVG magnetic sensitivity along IA is $1.3^{*} 10^{-3} \mathrm{deg} / \mathrm{s} / \mathrm{mT}$, and perpendicular to IA it is $1.7 * 10^{-4} \mathrm{deg} / \mathrm{s} / \mathrm{mT}$. Rejection factors in term of magnetic sensitivities along and perpendicular to IA are respectively equal to 10 and 25 . The greater the magnetic field, the greater the rejection factor of differential CVG in comparison to rate one. Differential CVG response to variable magnetic field for not great of its amplitude is invisible on the background of low-cost CVG noise.

This investigation has been carried out for standing wave angle $\theta^{*}$, that equalizes $X$ and $Y$ channel scale factors. It will be interesting to conduct investigation on disturbances sensitivity for standing wave angle $\theta_{0}$, that equalizes $X$ and $Y$ channel biases.

\section{References}

1. D.D. Lynch "Coriolis Vibratory Gyroscope, IEEE Standard Specification Format Guide and Test Procedure for Coriolis Vibratory Gyros", IEEE std.1431 ${ }^{T M}$, Annex B, pp. 56-66, Dec. 2004.

2.J.A. Gregory "Characterization Control and Compensation of MEMS Rate and Rate-Integrating Gyroscopes".Ph.D. Dissertation, Michigan University, P.198, 2012.

3. V.V. Chikovani, O.A. Suschenko "Differential mode of operation for ring-like resonator CVG", IEEE Proc. Intern. Conf. on Electronics and Nanotechnology, Kyiv, Ukraine, pp. 451-455, 15-18 April 2014.

4 V.V. Chikovani, H.V. Tsiruk "Differential Mode of Operation for Multimode Vibratory Gyroscope”, IEEE Proc. Intern. Conf. on Actual Problem of Unmanned Aerial vehicles Development (APUAVD), NAU, Kyiv, Ukraine, pp. 87-90, Oct.13-15, 2015.

5. V.V. Chikovani, H.V. Tsiruk "Differential CVG shock damping capacity. Computer simulation results".- IEEE Proc. Intern. Conf. on Methods and Systems of Navigation and Motion Control (MSNMC), NAU, Kyiv, Ukraine, Oct.14-17, 2014, pp.132-134.

6. V. Chikovani, O. Suschenko, H. Tsiruk "Redundant Information Processing Techniques Comparison For Differential Vibratory Gyroscope".- Eastern-European Journal of Enterprise Technologies 4/7 (82), 2016, pp. 45-52.

7. V.V. Chikovani, H.V. Tsiruk, "Viratory gyro accuracy parameters improving by means of excitation control".Elelectronics and Control Systems, \#3 (37), 2013, pp. 43-48.

8. D.D. Lynch, "Vibratory gyro analysis by the method of averaging," in 2nd St. Petersburg Int. Conf. on Gyroscopic Technology and Navigation, St. Petersburg, Russia, 1995, pp. 26-34.

9. Y. Son, H. Shin, D. Kim, Y. Park, J. Noh, K. Choi, J. Choi, Y. Kim: Rocking Drones with Intentional Sound Noise on Gyroscopic Sensors, Proc. of the 24th USENIX Security Symposium, Washington, D.C., August 12-14, 2015.

10. G. Roth: Simulation of the Effects of Acoustic Noise on MEMS Gyroscope, MS Thesis, Auburn University, P.101, 2009.

11. W.N. Yunker, C.B. Stevens, T. F. George, R.N Dean: Sound attenuation using microelectromechanical systems fabricated acoustic metamaterials, Journal of Applied Physics, v. 113, 024906, 2013. http://dx.doi.org/10.1063/1.4774021.

12. P. Soobramaney: Mitigation of the Effects of High Levels of High-Frequency Noise on MEMS Gyroscopes, Ph.D. Dissertation, Auburn University, Alabama, P. 200, 3Aug. 2013.

13. V.V. Chikovani, H.V. Tsiruk, A.N. Beregovoy, V.N. Makarenko, V.O. Paraschanov "Influence of External Acoustic Disturbances on Differential Vibratory Gyroscope Output Signals".-Proc. 2016 IEEE 4th International 
Conference on Methods and Systems of Navigation and Motion Control, October 18-20, 2016 Kyiv, Ukraine, pp.95-97.
Рецензент: д.т.н., проф. В.М. Азарсков, Національний авіаційний університет, Київ.

Ефективне придушення обурень від акустичних і магнітних полів диференціальним вібраційних гіроскопом 3 однісю вібраційною масою

\author{
В.В. Чіковані, Г.В. Цірук
}

В роботі аналізується диферениійний режсим роботи вібраційного гіроскопа в якості третього режиму на відміну від пермого - режиму вимірювання кутової швидкості і другого - інтегруючого режиму. У диференціальному режимі роботи стояча хвиля стримується між електродами. В иьому випадку утворюються два Хі Ү вимірювальних канали $з$ протилежними знаками кутових швидкостей. Зсуви нулів і масштабні коефіцієнти вимірювальних каналів $X$ i $Y$ залежать від кутового положення $\theta$ стоячої хвилі відносно електрода збудження $X$. Існує кутове положення $\theta^{*}$, при якому масштабний коефіцієнт $S F_{x}$ каналу $X$ дорівнює масштабному коефіиієнту $S F_{y}$ каналу $Y . \quad$ чиій статті експериментально визначаються коефіцієнти придушення як зовнішніх акустичних імпульсів, частота яких близька до резонансної, так і постійних $i$ змінних магнітних полів у разі, коли стояча хвиля знаходиться в кутовому положенні $\theta^{*}$. В протилежність іншим типам диференціальних гіроскопів, які можуть бути реалізовані, використовуючи дво- або багатомасові конструкиіі резонатора, в гіроскопах з одномасовими резонаторами можуть бути досягнуті вищі коефічієнти придушення різних обурень, коли стояча хвиля знаходиться в положенні $\theta^{*}$, забезпечуючи задоволення вимогам багатьох важслиих застосувань. Результати випробувань показують чудові властивості пригнічення обурень диференціальним режимом роботи вібраційного гіроскопа з одномасовим резонатором. У роботі також проводиться порівняння відгуків на обурення диферениіального режиму і режиму виміру кутової швидкості того ж гіроскопа.

Ключові слова: диференціальний гіроскоп, коефіцієнт пригнічення, акустичні збурення, чутливість до магнітного поля.

\title{
Эффективное подавление возмущений от акустических и магнитных полей дифференциальным вибрационным гироскопом с одной вибрационной массой
}

\section{В.В. Чиковани, А.В. Цирук}

В работе анализируется дифференциальный режим работы вибрационного гироскопа в качестве третьего режима в отличие от первого - режима измерения угловой скорости и второго - интегрирующего режима. $B$ дифференциальном режиме работы стоячая волна удерживается между электродами. В этом случае образуются два Х и Y измерительных канала с противоположными знаками угловых скоростей. Смещения нуля и масштабные коэффициенты измерительных каналов $X$ и $Y$ зависят от углового положения $\theta$ стоячей волны относительно электрода возбуждения X. Существует угловое положение $\theta^{*}$, при котором масштабный коэффициент $S F_{x}$ канала $X$ равен маситабному коэффичиенту $S F_{y}$ канала $Y$. В этой статье экспериментально определяются коэффициенты подавления, как внешних акустических импульсов, частота которых близка к резонансной, так и постоянных и переменных магнитных полей в случае, когда стоячая волна находится в угловом положении $\theta^{*}$. В противоположность другим типам дифференцииальных гироскопов, которые могут быть реализованы, используя двух- или многомассовые конструкции резонатора, у гироскопов с одномассовыми резонаторами могут быть достигнуты более высокие коэффичиенты подавления различных возмущений, когда стоячая волна находится в положении $\theta^{*}$, обеспечивая удовлетворение требований многих важных применений. Результаты испытаний показывают превосходные свойства подавления возмущений дифференциальным режимом работы вибрачионного гироскопа с одномассовым резонатором. В работе также проводится сравнение откликов на возмущение дифференциального режима и режима измерения угловой скорости того же гироскопа.

Ключевые слова: дифференцилальный гироскоп, коэффичиент подавления, акустические возмущения, чувствительность к магнитному полю. 